\title{
Bacteriological and physicochemical analyses of well water used for drinking in Ekpoma-Edo State, Nigeria
}

\begin{abstract}
In this Study, ten (10) samples of well water was randomly collected from different locations around Ekpoma, Esan West Local Government Area of Edo State and examined for their physicochemical and Microbiological quality using standard methods. The results derived were compared with the Nigerian Industrial Standards (NIS) and World Health Organisation (WHO) standards for drinking water. Three (3) of the samples did not agree with turbidity, while others were within the maximum permissible limits set for $\mathrm{pH}$, temperature, colour, odour, conductivity, dissolved oxygen, alkalinity, acidity, chloride and biological oxygen demand. The findings of the microbiological analysis of the well water samples show that all the well water was contaminated with bacteria pathogens mostly Escherichia coli (60\%), Pseudomonas aeruginosa (50\%), Staphylococcus aureus (50\%), Salmonella Sp (30\%), Shigella sp (40\%), Vibrio chloreae (30\%) and Proteus sp (50\%). The presences of these bacteria in the samples were at variance with the acceptable limit for most probable number (MPN) per $100 \mathrm{ml}$ set for untreated drinking water. Pathogen enumeration for SalmonellaShigella and Vibrio cholerae were high. The total aerobic bacteria counts (ABC) were also high for all the sample areas assessed. The occurrence of these microbes in the well water used for drinking, washing of meats and for ablution is germane to public health because they are often implicated with gastro-intestinal water borne infections. Thus personal hygiene and clean environment should be constantly maintained around the wells to avoid contamination with bacteria pathogens.
\end{abstract}

Keywords: well water, physicochemical, microbiological, contamination, most probable number (MPN), aerobic bacterial count (ABC), heterotrophic plate count (HPC), coliforms
Volume 7 Issue 6 - 2019

\author{
Osatohanmwen Osarenmwinda, Aruya \\ Graceann Idaehor \\ Department of Microbiology, Ambrose Alli University, P.M. B I4 \\ Ekpoma, Edo State, Nigeria
}

Correspondence: Osatohanmwen Osarenmwinda, Department of Microbiology, Ambrose Alli University, Ekpoma, Edo State, Nigeria, Tel +2348067|784I 9 \& 080773 I4480,

Email osato.oses@aauekpoma.edu.ng

Received: October 18,2019 | Published: November 14, 2019

\section{Introduction}

Portable water is a key requirement for human, whether it is intended for drinking, recreational activities and other domestic purposes. It is a vital desire for all life forms. It is therefore imperative that adequate amount of portable, clean and safe water be made available to other life forms such as flora and fauna. Inadequate quantity of it results to mobility and fatality rate in rural settlements where chemical contaminants and water-based infections are endemic and persistent because of poor groundwater and surface waters quality. ${ }^{1}$ The global health importance of water quality is a concept that needs not to be neglected as quite a number of infectious diseases are contracted by water via faecal-oral mode of transmission. These infections have been reported of having a fatality rate of 5 million children annually, causing $1 / 6^{\text {th }}$ of the world population ill. $^{2}$ Water borne infections emanate from intake of untreated contaminated water by pathogenic microbes. These infections are linked with the non-availability and accessibility to clean, portable water supply in addition to unhygienic vicinity. This affects man and the biotic components of the ecosystem especially in developing countries. The following bacteria genera are often incriminated in water based infections; Pseudomonas aeruginosa, Shigella sonnei, Salmonella, Klebsiella, lyanobacteria, Proteus, Vibrio, Mycobacteria, Streptococcus faecalis e.t.c. ${ }^{3}$ Fresh water which lies below the earth crust in broken segments of rocks and soil pore spaces is considered as groundwater. It is often regarded as an ideal source of water because it is seem not to be opaque and clean. This is attributed to its passage via various layers and sediments of rocks, which act as a sort of natural filtration system. However it portability and quality can be compromise as a result of poor source protection and resource management. ${ }^{4}$ There is an increase in the spite of ground water contamination especially in urban settlements with variety of industrial activities, increase in the number of inhabitants, poor hygiene, use of land for mechanized and commercial farming and indiscriminate disposal of wastes on land. ${ }^{5}$ The presence of contaminants whether inorganic or organic in the ground water above maximum limits sets by water regulatory agencies such as WHO, EPA, NIS and FEPA may cause a serious health calamity. ${ }^{6}$ Inhabitants of developing countries unavoidably still rely on contaminated ground water due to non availability of potable water sources. ${ }^{7}$ Water apart from its domestic applications has various other aspect of use such as transportation, generation of hydro-power electricity, irrigation and aquaculture. It is a major driving force that controls the evolution and functionality of the universe on earth. ${ }^{8}$ Varieties of artificial chemicals pollutants such as insecticides, pesticides, nitrates from fertilizers, sulphates, chlorides, phenols, soap and heavy metals e.t.c are chief contributors to water contamination. Cadmium, arsenic, lead, zinc, iron, copper and manganese are severe and hazardous pollutants among the heavy metals. ${ }^{8}$ Water being a basic need for our daily living, makes it pertinent for thorough physicochemical and bacteriological investigations to be conducted on it. Therefore this study is gear towards ascertaining the well water quality used for drinking in Ekpoma, Edo State Nigeria in line with checking its conformity with standards set by water regulatory bodies such as WHO and NIS as well as to determined the likely causes of pollution in other to make valid recommendations 


\section{Materials and methods}

\section{Sampling technique and Sample vicinity}

This assessment was done in Ekpoma environs domiciliated in Esan-West Local Government Area of Edo State. It has an area of $502 \mathrm{~km}^{2}$ with about 190,000 people who comprise an adult male population of over 60,000 and adult female population of 50,000 respectively. It lies on a geographical coordinate of latitude $6^{\circ} 45^{\prime} \mathrm{N}$ $6^{\circ} 08^{\prime} \mathrm{E}$ and has an elevation of approximately 364 meters above sea level. ${ }^{9}$ Randomly Ten (10) samples of well water samples were obtained from ten different hand-dug wells within the study area. The samples were represented as A, B, C, D, E, F, G, H, I and J respectively. Sample A is well water from St. David Hostel, B is well water from an abattoir located at Ujoelen extension, $\mathrm{C}$ is well water from Good shepherd hostel, D is well water from Ambrose hostel, E is well water from Success hostel, $\mathrm{F}$ is well water from Lekki villa hostel, $\mathrm{G}$ is well water from yard six hostel, $\mathrm{H}$ is well water from an abattoir located in Iruekpen, I is also well water from an abattoir located on the Benin-Auchi express road and $\mathrm{J}$ is well water from Galaxy hostel. Three (3) out of the ten wells were location within an abattoir, hence serving as a water source for drinking, washing of meat and meat products and also to perform ablution. The samples were obtained into sterile universal bottles and kept in an insulated ice box at a temperature of $1-4^{\circ} \mathrm{C}$ before transporting them to the laboratory where physicochemical and bacteriological analyses was carried out within 6hours of collection.

\section{Sample analysis}

Physicochemical parameters namely determination of temperature, $\mathrm{pH}$, biological oxygen demand, turbidity, odour, colour, electrical conductivity, dissolved oxygen, acidity, alkalinity and chloride content were determined using accepted methods for wastewater and water assessment. ${ }^{2,10}$ Bacteriological traits were assessed as described by Bezuidenhout et al. ${ }^{11}$ The Multiple tube fermentation technique was applied for coliform enumeration in the well water samples and compare with the bacteria load in the MaCcrady table. ${ }^{10}$ SalmonellaShigella Agar, Nutrient agar, MacConkey agar medium, Thiosulphate Citrate Bile Salt Sucrose agar (TCBS) were used to evaluate the Aerobic Bacteria Count (ABC) for Salmonella, Vibrio and Shigella respectively. The Petri dish plates were kept and maintained at a temperature $37^{\circ} \mathrm{C}$ for 24 hours using the incubator. Presumptive colonies of bacteria isolates were verified by biochemical reaction methods as described by SCA. ${ }^{12}$

\section{Results}

The findings of the physicochemical analysis conducted on the samples of well water showed variation in the parameters determined (Table 1). Turbidity was within the set limits by World Health Organisation and Nigeria Industrial Standards use for monitoring drinking water quality in some of the sample areas except well water B, $\mathrm{H}$ and I respectively. All the samples analysed had temperature values which ranged from $25-34^{\circ} \mathrm{C}$ and were in line with limits of established standards. The $\mathrm{pH}$ ranged from 6.8-7.4 while the acidity and alkalinity values ranged from $0.1-0.3$ and $7.1-8.2 \mathrm{mg} / \mathrm{L}$ respectively. Sample B had the highest colour of $12 \mathrm{HU}$, while sample $\mathrm{E}$ had the lowest colour value of $4 \mathrm{HU}$. The water samples examined had no objectionable odour. Conductivity value measured as $(\mu \mathrm{s} / \mathrm{cm})$ gave a reading ranged of $60.20-12.8$. Well water $\mathrm{F}$ had the least conductivity reading of $60.20 \mu \mathrm{s} / \mathrm{cm}$ whilst sample J obtained within an abattoir premises gave the highest conductivity value of $120.8 \mu \mathrm{s} / \mathrm{cm}$. Chloride ranged was from $113-210 \mathrm{mg} / \mathrm{L}$. Findings of the bacteriological investigation of the well water samples are represented in (Table 2). The total aerobic bacteria count $(\mathrm{ABC})$ for the water samples were high ranging from $2.6 \times 10^{2} \mathrm{cfu} / \mathrm{ml}-7.1 \times 10^{5} \mathrm{cfu} / \mathrm{ml}$. The abattoir well water sample in site I had the highest bacteria load of $7.1 \times 10^{5} \mathrm{cfu} / \mathrm{ml}$, while well water sample $\mathrm{E}$ had the lowest value of $2.6 \times 10^{2} \mathrm{cfu} / \mathrm{ml}$. Vibrio cholerae count of the water samples ranged is from $6.0 \times 10^{2} \mathrm{cfu} / \mathrm{ml}-2.8 \mathrm{x}$ $10^{4} \mathrm{cfu} / \mathrm{ml}$, with well water B having the least count of $6.0 \times 10^{2} \mathrm{cfu} / \mathrm{ml}$ and well water I having the highest the count of $2.8 \times 10^{2} \mathrm{cfu} / \mathrm{ml}$. The other sample sites except well water $\mathrm{H}$ with $5.0 \times 10^{3} \mathrm{cfu} / \mathrm{ml}$ displayed absence of Vibrio spp growth. Salmonella and Shigella enumeration for the water samples gave values ranging from $2.5 \times 10^{2} \mathrm{cfu} / \mathrm{ml}-1.9 \mathrm{x}$ $10^{4} \mathrm{cfu} / \mathrm{ml}$, with well water $\mathrm{H}$ having the highest count of $1.9 \times 10^{4} \mathrm{cfu} /$ $\mathrm{ml}$ while well water B had the lowest count of $2.5 \times 10^{2} \mathrm{cfu} / \mathrm{ml}$. All other sample sites except well water I with $2.7 \times 10^{2} \mathrm{cfu} / \mathrm{ml}$ showed no growth of Salmonella and Shigella. (Table 3) shows the presumptive coliform enumeration using the multiple tube fermentation methods (MPN) for the different sample sites..$^{13}$ The total coliform counts of all the water samples ranged from 24 to $>1,800 \mathrm{MPN} / 100 \mathrm{ml}$. Well water I had a total coliform count $>1,800 \mathrm{MPN} / 100 \mathrm{ml}$, while well water $\mathrm{F}$ had the least count of $24 \mathrm{MPN} / 100 \mathrm{ml}$. A comparative assessment of turbidity and total coliform bacteria in the well water samples was done using Statistical Package for Scientific Solution (IBM SPSS version 25). The finding revealed a strong positive correlation having $\mathrm{R}$ value for turbidity as 0.915 and $\mathrm{p}$ value at 0.01 . This correlation between these two parameters indicates that as turbidity decrease, total coliform bacteria decrease vice versa. This result is in line with those reported by Busse et al., ${ }^{14} \&$ Ali et al. ${ }^{15}$ The bacteria implicated in the water samples in this study were Escherichia coli, Proteus sp Staphylococcus aureus, Pseudomonas aeruginosa, Shigella spp, Vibrio chloreae Salmonella sp (Table 4).

\section{Discussion}

Turbidity according to $\mathrm{EPA}^{13}$ is the extent of cloudiness in water. There is a direct correlation between total amount of suspended solid and turbidity. Thus the higher the amount of solids suspended the more turbid the water appears. High turbidity values are a direct reflection of high pathogenic organism's levels. Turbidity levels of some analyzed samples lies within the limits of established standards. Temperatures of all the samples investigated were within the NIS and WHO standards set by water regulatory agencies. $\mathrm{pH}$ of all the samples conform with NIS and WHO permissible limits of 6.50-7.50 and 6.508.50 respectively. The $\mathrm{pH}$ of well water $\mathrm{B}$ and $\mathrm{H}$ indicates that the well water were slightly acidic. Adefemi \& Awokunmi ${ }^{16}$ reported acidic water as a cause of rust in cooking equipments, corrosion in steel and pipes which eventually results in clogging and unpleasant odour in food and drinks. The colour of all the water samples examined were in line with the recommendations by EPA which is $15 \mathrm{HU} .{ }^{13}$ The water samples under examination had no unobjectionable odour which is also in line with the recommended standard for drinking water which is threshold odour number ${ }^{13}$ Alkalinity and acidity values were at variance falling below the WHO and NIS maximum limits of $200 \mathrm{mg} / 1$ and $0.3 \mathrm{ML}$, though no standard limits for alkalinity by NIS. Chloride ion (CL-) amount in all samples examined were below the established standards limits of $250 \mathrm{mg} / \mathrm{L}$ and $200 \mathrm{mg} / \mathrm{L}$ by the WHO and NIS. Ekpete ${ }^{17}$ reported that high concentration of chloride ion in water may results to edema. The Aerobic Bacteria count (ABC) measure colony formation by the total, viable and aerobic bacteria present in a sample on appropriate culture media after incubation at suitable temperature. 
The total bacteria counts for all the well water samples examined exceeded the limits of $1.0 \times 10^{2} \mathrm{cfu} / \mathrm{ml}$ which is the limit for aerobic bacteria count for drinking water. ${ }^{2}$ The microbial enumeration was higher in well water situated within the abattoir premises. High bacteria pollution recorded in this study may be linked to both the settlement pattern and placement of the well which is often too close to sanitation systems. The bacteria contamination of the wells around the abattoir is likely of human origin. This fairly dense populated region enhances the use of inadequate septic soak away and pit latrines often sited too close to the wells. Furthermore free movement of domestic animals and other domestic solid wastes disposed around the houses are likely sources of bacterial contamination of the wells in the other sample sites. The presume coliform counts (MPN) for some of the samples of well water were higher than the limits set by $\mathrm{EPA}^{18} \& \mathrm{WHO}^{2}$ for coliform bacteria in drinking water which is zero total coliform $/ 100 \mathrm{ml}$ of water, except well water C and G with $10 \mathrm{MPN} / 100 \mathrm{ml}$. This is in agreement with NIS standard. ${ }^{19}$ The count of Shigella, Vibrio cholera, Salmonella and in three of the well water samples B, H and I is a clear deviation from the WHO standard for drinking water. Which clearly reveal that these virulent organisms must not be found in water because they are of public health importance, having been linked with gastrointestinal illness such as typhoid, diarrhoea, dysentery and other forms of infections. ${ }^{18}$ The absence of these pathogens in the other water samples in this study may be a reflection on the depth of the well among several other contributory risk factors. Other bacteria isolated in this study include; Escherichia coli, Proteus spp, Staphylococcus aureus and Pseudomonas aeruginosa which collectively belongs to the intestinal flora, but is also widely isolated in soil and water. ${ }^{20}$ Staphylococcus aureus produces enterotoxin, from the outcome of the bacteria identification conducted it is clear that diseases such as food poisoning, typhoid fever, cholera and bacteria dysentery can likely arise from the ingestion of these untreated well water. Furthermore throat infections, nose, skin, eye and ear disorders can also spread from contact with these water. The prevalence of these bacteria shows that the sanitary status of the shallow wells especially those within the abattoir areas are very low.

Table I Physicochemical analyses of well water samples

\begin{tabular}{|c|c|c|c|c|c|c|c|c|c|c|c|c|}
\hline $\begin{array}{l}\text { Parameters } \\
\text { Analyzed }\end{array}$ & $\begin{array}{l}\text { Sample } \\
\text { A }\end{array}$ & $\begin{array}{l}\text { Sample } \\
\text { B }\end{array}$ & $\begin{array}{l}\text { Sample } \\
\text { C }\end{array}$ & $\begin{array}{l}\text { Sample } \\
\text { D }\end{array}$ & $\begin{array}{l}\text { Sample } \\
\text { E }\end{array}$ & $\begin{array}{l}\text { Sample } \\
\text { F }\end{array}$ & $\begin{array}{l}\text { Sample } \\
\text { G }\end{array}$ & $\begin{array}{l}\text { Sample } \\
\text { H }\end{array}$ & $\begin{array}{l}\text { Sample } \\
\text { I }\end{array}$ & $\begin{array}{l}\text { Sample } \\
\text { J }\end{array}$ & $\begin{array}{l}\text { WHO } \\
\text { standard }\end{array}$ & $\begin{array}{l}\text { NIS } \\
\text { standard }\end{array}$ \\
\hline $\begin{array}{l}\text { Temperature } \\
\left({ }^{\circ} \mathrm{C}\right)\end{array}$ & 29 & 34 & 25 & 28 & 25 & 30 & 29 & 34 & 33 & 25 & $25-36$ & $25-32$ \\
\hline $\mathrm{pH}$ & 7.06 & 6.8 & 7.38 & 7.01 & 7.4 & 7.05 & 7.02 & 6.9 & 7.04 & 7.2 & $6.5-8.5$ & $6.5-7.5$ \\
\hline $\begin{array}{l}\text { Turbidity } \\
\text { (NTU) }\end{array}$ & 0 & 6.05 & 0.9 & 0.98 & 0.7 & 0.6 & 0.7 & 7.01 & 8 & 0.86 & $5-6$ & 5 \\
\hline \multicolumn{13}{|l|}{ Biological } \\
\hline $\begin{array}{l}\text { Oxygen } \\
\text { Demand } \\
(\mathrm{mg} / \mathrm{L})\end{array}$ & 2.15 & 2 & 3.5 & 3.1 & 3.12 & 2.5 & 2.4 & 2.2 & 2.22 & 2.5 & NS & NS \\
\hline Odour & $U$ & $u$ & $U$ & $U$ & $u$ & $u$ & $u$ & $u$ & $U$ & $U$ & $U$ & $u$ \\
\hline Colour (HU) & 5 & 12 & 5 & 10 & 4 & 15 & 7 & 8 & 10 & 8 & 6 & 15 \\
\hline $\begin{array}{l}\text { Conductivity } \\
(\mu \mathrm{s} / \mathrm{cm})\end{array}$ & 75.2 & 73.4 & 71.2 & 82.3 & 67.4 & 60.2 & 85 & 100 & 115.5 & 120.8 & 300 & 1000 \\
\hline \multicolumn{13}{|l|}{ Dissolved } \\
\hline $\begin{array}{l}\text { Oxygen } \\
(\mathrm{mg} / \mathrm{L})\end{array}$ & 0.3 & 3 & 0.8 & 0.2 & 0.4 & 0.3 & 0.3 & 0.6 & 0.2 & 0.2 & NAD & NAD \\
\hline $\begin{array}{l}\text { Alkalinity } \\
(\mathrm{mg} / \mathrm{L})\end{array}$ & 7.14 & 7.1 & 7.2 & 7.5 & 8.2 & 7.68 & 7.26 & 7.3 & 7.2 & 7.1 & 200 & NS \\
\hline Acidity(mg/L) & 0.2 & 0.3 & 0.1 & 0.1 & 0.2 & 0.1 & 0.2 & 0.3 & 0.3 & 0.1 & 0.3 & 0.3 \\
\hline $\begin{array}{l}\text { Chloride } \\
(\mathrm{mg} / \mathrm{L})\end{array}$ & 157 & 113 & 189 & 190 & 171 & 161 & 185 & 210 & 200 & 170 & 250 & 200 \\
\hline
\end{tabular}

$\mathrm{U}$, unobjectionable; NAD, no available data; NS, no standard

Legend: Sample A, well water from St. David Hostel; B, well water from an abattoir located at Ujoelen extension; C, well water from Good shepherd hostel; D, well water from Ambrose hostel; $E$, well water from Success hostel; $F$, well water from Lekki villa hostel; $G$, well water from yard six hostel; $H$, well water from an abattoir located in Iruekpen; I, well water from an abattoir located on the Benin-Auchi express road; J, well water from Galaxy hostel 
Table 2 Bacteriological analysis of well water

\begin{tabular}{|c|c|c|c|c|}
\hline Well water & $\begin{array}{l}\text { Total aerobic } \\
\text { bacteria count } \\
(\mathrm{cfu} / \mathrm{ml})\end{array}$ & $\begin{array}{l}\text { Total coliform } \\
\text { count(MPN//00ml) }\end{array}$ & $\begin{array}{l}\text { Salmonella-Shigella } \\
\text { count(cfu/ml) }\end{array}$ & $\begin{array}{l}\text { Vibro chloreae } \\
\text { count(cfu/ml) }\end{array}$ \\
\hline A & $1.3 \times 10^{4}$ & 130 & Not detected & Not detected \\
\hline$B$ & $4.5 \times 10^{2}$ & 430 & $2.5 \times 10^{2}$ & $6.0 \times 10^{2}$ \\
\hline C & $1.2 \times 10^{5}$ & 10 & Not detected & Not detected \\
\hline$D$ & $6.2 \times 10^{4}$ & 52 & Not detected & Not detected \\
\hline$E$ & $2.6 \times 10^{2}$ & 31 & Not detected & Not detected \\
\hline $\mathrm{F}$ & $2.4 \times 10^{3}$ & 24 & Not detected & Not detected \\
\hline G & $1.2 \times 10^{4}$ & 10 & Not detected & Not detected \\
\hline $\mathrm{H}$ & $6.9 \times 10^{5}$ & 1600 & $1.9 \times 10^{4}$ & $5.0 \times 10^{3}$ \\
\hline I & $7.1 \times 10^{5}$ & $>1800$ & $2.7 \times 10^{2}$ & $2.8 \times 10^{4}$ \\
\hline$J$ & $1.8 \times 10^{3}$ & 15 & Not detected & Not detected \\
\hline WHO standard & $1.0 \times 10^{2}$ & Zero/I00ml & Zero & Zero \\
\hline NIS standard & $1.0 \times 10^{2}$ & I0CFU/I00ml & Zero & Zero \\
\hline
\end{tabular}

Table 3 Presumptive Coliform count of the well water samples

\begin{tabular}{lllll}
\hline Samples & $\begin{array}{l}\text { IOml tubes } \\
\text { Positive }\end{array}$ & $\begin{array}{l}\text { Iml tubes } \\
\text { Positive }\end{array}$ & $\begin{array}{l}\text { O.Iml tubes } \\
\text { Positive }\end{array}$ & $\begin{array}{l}\text { Most Probable } \\
\text { Number (MPN) per } \\
\text { I00ml }\end{array}$ \\
\hline A & 5 & 4 & 0 & 130 \\
B & 5 & 4 & 5 & 430 \\
C & I & 2 & 2 & 10 \\
D & 4 & 3 & 4 & 52 \\
E & 3 & 2 & 5 & 31 \\
F & 3 & 2 & 3 & 24 \\
G & I & 2 & 2 & 10 \\
H & 5 & 5 & 4 & 1600 \\
I & 5 & 5 & 5 & $>1800$ \\
J & 2 & 4 & 0 & 15 \\
\hline
\end{tabular}

Table 4 Bacterial isolates from well water samples

\begin{tabular}{|c|c|c|c|c|c|c|c|c|c|c|}
\hline $\begin{array}{l}\text { Bacterial } \\
\text { isolates }\end{array}$ & $\begin{array}{l}\text { Well } \\
\text { water A }\end{array}$ & $\begin{array}{l}\text { Well } \\
\text { water B }\end{array}$ & $\begin{array}{l}\text { Well } \\
\text { water C }\end{array}$ & $\begin{array}{l}\text { Well } \\
\text { water D }\end{array}$ & $\begin{array}{l}\text { Well } \\
\text { Water E }\end{array}$ & $\begin{array}{l}\text { Well } \\
\text { water F }\end{array}$ & $\begin{array}{l}\text { Well } \\
\text { water G }\end{array}$ & $\begin{array}{l}\text { Well } \\
\text { water H }\end{array}$ & $\begin{array}{l}\text { Well } \\
\text { water I }\end{array}$ & $\begin{array}{l}\text { Well } \\
\text { water J }\end{array}$ \\
\hline Escherichia coli & - & + & - & - & - & + & + & + & + & + \\
\hline $\begin{array}{l}\text { Pseudomonas } \\
\text { aeruginosa }\end{array}$ & - & + & - & + & - & + & - & + & + & - \\
\hline $\begin{array}{l}\text { Staphylococcus } \\
\text { aureus }\end{array}$ & - & + & - & - & + & - & + & + & + & - \\
\hline Salmonella spp & - & + & - & - & - & - & - & + & + & - \\
\hline Shigella spp & - & + & - & + & - & - & - & + & + & - \\
\hline Vibrio chloreae & - & + & - & - & - & - & - & + & + & - \\
\hline Proteus spp & - & + & + & - & + & - & - & + & + & - \\
\hline
\end{tabular}

Key: +, Present; -, Absent 


\section{Conclusion and recommendation}

This study revealed that most physicochemical parameters evaluated were within the WHO and NIS standard for drinking water except turbidity in few of the sample areas. It is obvious from the study that water borne infections emanate from inadequate disposal of refuse, pollution of water by sewage, therefore programmes must be organise to lower the outspread incidence of pollution in the well water. It is advocated that well dug must be deep and covered adequately. Local latrines and septic collection tanks should be located very far away from the wells, boiling and other disinfection methods of well water obtained in the study area should be done before usage of the water. Also good personal and environmental hygienic practices must be a norm around the wells.

\section{Acknowledgments}

The authors are grateful to Dr. Clement Isaac and the Department of Microbiology, Ekpoma, Edo State, Nigeria for providing the necessary facilities used in this study.

\section{Conflicts of interest}

Authors have declared that no competing interests exist.

\section{References}

1. Basavaraja Simpi SM, Heremath KNS, Mmurthy KN, et al. Analysis of water quality using physico-chemical parameters. Hosahalli Tonk in Shimaga District, Karnataka, India. Global J Sci Frontiel Res. 2011;11(3):31-34.

2. Water Sanitation and Health Programme. Managing water in the home: accelerated health gains from improved water sources. World Health Organisation; 2004.

3. Chris N. Comprehensive Biology for Senior Secondary Schools. Johnson publishers Limited: Surulere, Lagos, New Edition; 2004.

4. Pedley S, Howard G. The public Health implications of microbiological contamination of Groundwater. $Q J$ Eng Geol Hydroge. 1997;30(2):179-188.

5. Egila JN, Terlumun A. A preliminary investigation into the quality of surface water in the Benue cement plc. Gboko- Benue State, Nigeria. Int J Sci Tech. 2004;3(1):12-17.

6. United States Environmental Protection Agency (USEPA). Methods for measuring the acute toxicity of effluents and receiving waters to freshwater and marine organisms. 5th ed. US Environmental; 2002. 275 p.
7. Stephen Odonkor T, Kennedy Addo K. Bacteriological profile and physico-chemical quality of ground water; a case study of borehole water sources in a rural Ghanian Community. Int J Curr Microbiol App Sci. 2013;2(8):21-40.

8. Kataria HC, Gupta M, Kumar M, et al. Study of physicochemical parameters of Drinking water of Bhopal city with Reference to health Impacts. Curr World Environ. 2011;6(1):95-99.

9. Okun R, Okosun M. An Overview of the Esan West Local Government. The Journal for Geographical Placement for Ekpoma Community. 1990;15(4):259-265.

10. Standard Methods for the Examination of Water and Wastewater. 19th ed. APHA: Washington DC; 1995. 2-56 p.

11. Bezuldenhout CC, Mthembu N, Puckree T, et al. Microbiological evaluation of the Mhlathuze River, Kwazulu-Natal (RSA). Water SA. 2002;28(3):281-286.

12. The microbiology of drinking water- Part 1 -Water quality and public health. Methods for the examination of waters and associated materials. Standing Committe of Analysis; 2002. 50 p.

13. US Environmental Protection Agency. Safe Drinking water Act Ammendment. EPA; 2002.

14. Busse El, Parish BK, Hollabaugh CL, et al. The correlation of fecal coliform and turbidity of the little Tallapoosa River in the west Geergia Region. GSA Annual Denver meeting; 2007.

15. Ali ZN, Imam MM, Abdulkadir FM. Physicochemical and bacteriological analysis of well water in Zango-Abattoir Kaduna- Nigeria. Nigerian Journal of Chemical Research. 2012;17:16-22.

16. Adefemi SO, Awokunmi EE. Determination of physicochemical parameters and heavy metals in water sample from Itaogbolu area of Ondo-State, Nigeria. Afr J Env Sci Tech. 2010;4(3):145-148.

17. Ekpete OA. Determination of physicochemical parameters in borehole water in Odihologboji community in Rivers State. Afri J Interdiscip Stu. 2002;3(1):23-27.

18. US Environmental Protection Agency. Safe Drinking water Act. EPA; 2003.

19. Nigerian standard for Drinking water quality NSDWQ. NIS 554:2007. Approved by SON Governing Council; 2007. 28 p.

20. Schlegel HG. General Microbiology. 7th ed. Cambridge University Press; 2002. 480 p. 